\title{
Compensations for Avoided Deforestation in the Brazilian Amazon: Implications from Direct Payments
}

\author{
Cecilia Gonçalves Simões (Corresponding author) \\ Graduate School of Life and Environmental Sciences, University of Tsukuba \\ 1-1-1 Ten-noudai, Tsukuba, Ibaraki 305-8572, Japan \\ Tel: 81-029-853-4633Ｅ-mail: sac.cia@gmail.com \\ Lavinia Poruschi \\ National Institute for Environmental Studies \\ 16-2 Onogawa, Tsukuba, Ibaraki 305-0062, Japan \\ Tel: 81-029-850-2672Ｅ-mail: lavinia.poruschi@nies.go.jp \\ Misa Masuda \\ Graduate School of Life and Environmental Sciences, University of Tsukuba \\ 1-1-1 Ten-noudai, Tsukuba, Ibaraki 305-8572, Japan \\ Tel: 81-029-853-4633 E-mail: masuda.misa.gm@u.tsukuba.ac.jp
}

The research was financed by International Tropical Timber Association, No. 088/08A (ITTO Fellowship Program)

\begin{abstract}
To significantly reduce emissions from deforestation and forest degradation, one of the main proposals of REDD schemes is to directly pay landowners for their opportunity cost. However, this idea gives little consideration to the conservation status of forested areas in small properties, ignoring that maybe direct payments will not bring a fair and equal distribution of benefits. This paper discusses implications the adoption of direct payments might have to smallholders in the Brazilian Amazon using a case study in the municipality of Cotriguaçu, Mato Grosso State. Interviews with landholders show that if the presence of a legal forest reserve, as determined by Brazilian Forest Code, is considered, the current environmental "deficit" found in most properties would represent the exclusion of thousands of smallholders from a direct compensation scheme, dramatically reducing the scope for REDD. The results show that alternative crediting schemes are needed for REDD to be equal and fair.
\end{abstract}

Keywords: REDD, Brazilian Amazon, Direct payments, Small farmers, Equality

\section{Introduction}

Reducing Emissions from Deforestation and Forest Degradation (REDD) is a form of payment for environmental services (PES) mechanism that has been considered and debated in the sphere of climate change mitigation actions particularly since 2005. In this mechanism, developing countries should receive financial incentives to support forestry practices that avoid changes to the forest cover in threatened areas, so that significant amounts of carbon emissions from the forest sector can be reduced (Angelsen et al., 2008).

The IPCC Assessment Report 4 (AR4) estimated that the activities from forestry and land use change release somewhere between six and sixteen percents of annual global carbon dioxide emissions (Intergovernmental Panel for Climate Change [IPCC], 2007). Agreement on the idea promoted in the AR 4 (Nabuurs et al., 2007] that abating LULUCF (Land Use, Land use Change and Forestry) greenhouse gas emissions is a lower cost option than others, rekindled interest in the idea of reducing emissions from deforestation, and turned REDD into a dominant subject in recent discussions on climate mitigation (Alvarado \& Wertz-Kanounnikoff, 2008).

Acknowledgement of the role forests and especially reducing deforestation can play in climate change mitigation has brought new perspectives as to how unsustainable deforestation can be abated and to new challenges for developing countries interested in this type of mechanism. In this case, Brazil, as holder/host of the world's 
largest tropical rainforest, where more than $70 \%$ of the country's emissions occur, can be considered as a primary candidate for a REDD program (Nepstad et al., 2007).

Since 1965 the Brazilian government has tried to control deforestation with the use of legal instruments, represented mainly by the Brazilian Forest Code (Código Florestal Brasileiro), or Law n ${ }^{\circ}$ 4.771. This law establishes the types of protected areas in Brazil and the regulation for their protection. In the case of rural private properties, the Forest Code establishes that landowners are required to keep a share of the property as a Legal Forest Reserve (LFR), an area that, in the Amazon, represents $80 \%$ of the total land area endorsed at the time the property is registered and where clear cutting is not allowed. More recently, other policy actions such as better rural licensing systems and increased fines for illegal logging have also been implemented with the same objective, but verified deforestation rates have proven that none of these efforts have been effective, showing that enforcing command-and-control policies is unlikely to work as a stand-alone strategy (Börner \& Wunder, 2008).

In face of this situation, REDD scheme proposals have suggested that direct payments to landowners can work as a better incentive for changes in land use practices in Brazil (Nepstad et al., 2007; Börner \& Wunder, 2008; Mato Grosso State Government [MT], Instituto Centro de Vida, \& The Nature Conservancy, 2009; Börner et al., 2010). However, it is the authors' belief that if direct payments are chosen as the crediting method, not enough attention will be given to areas that represent little additionality (significant verifiable reduction in carbon emissions in relation to a baseline [Costa et al., 2000]), or to landholders who own small areas of conserved forest. Since REDD funders are likely to be more interested in areas with higher additional reductions (Börner et al., 2010), which are usually represented by large properties owned by wealthy landowners (Fearnside, 2005, 2008; Ferraz et al., 2005; Kirby et al., 2006; Trancoso et al., 2007), it is most likely that direct payments will result in the concentration of REDD benefits to an elite, resulting in unequal distribution of funds.

To address this issue, this study approaches direct payments from the end point of the scheme, or the landholders' position. In order to analyze implications on the local level that might come from the implementation of a REDD program with focus on additionality and direct payments, this study investigates the current land-use system and its historical background in the municipality of Cotriguaçu, located in the "arc of deforestation" of the Amazon. Cotriguaçu's land-use system reflects the most common scenario found throughout the Legal Amazon, where the economy is centered on cattle ranching and where most of the territory is occupied by large properties. Many studies have described the impact cattle ranching has had on the Amazon forest (Malhi et al., 2008; Nepstad et al., 2006; Fearnside, 2005; Ferraz, 2005; Walker \& Moran, 2000), culminating with Ramankutty et al. (2007) showing that until $2003,62 \%$ of the deforested area was occupied by pasture. Given that the importance of beef production on the national economy is only expected to grow in the future due to global demands for food (Nepstad et al., 2008), the analysis of Cotriguaçu's socio-economic situation can give important insights on what a future REDD program in Brazil should focus on and how it could act to bring effective results.

\section{Case-study}

\subsection{Placement of Cotriguaçu in Brazil}

This study was conducted in the Cotriguaçu municipality, located in the Northwest region of Mato Grosso (S09 $57^{\prime} 27^{\prime \prime}$ W58 $24^{\prime} 49^{\prime \prime}$ ) (Fig. 1), a Brazilian State which, due to its location and its role as one of the champions of deforestation in Brazil, is expected to play a key role in the national and international climate scenario (MT et al., 2009).

Cotriguaçu was first established in an area bought by a cooperative from the western region of Paraná State called "Cental de Cooperativas Cotriguaçu", as an option of occupation for its small rural producers and their descendents. The colonization process started in 1984, and since the 90's, Cotriguaçu's territorry has also been occupied by three rural settlement projects established by the National Institute for Colonization and Agricultural Reform (INCRA), namely "Cedere", "Nova Cotriguaçu" and "Juruena", and one established by the State Agency INTERMAT, named "Sonho Meu". These settlement areas have been attracting a great number of families mainly from the States of Mato Grosso and Rondônia, and nowadays they are occupied by more than 1500 families (MT et al. 2009).

Although Cotriguaçu occupies a total area of 912358 ha, $33.2 \%$ of its territory corresponds to protected areas, being 18.5\% (168938 ha) indigenous land and 14.7\% (134116 ha) conservation units (Finger, unpublished data; MT et al., 2009). Currently there are no precise estimations on the proportion of private and vacant land, but according to the last national census of agriculture conducted by the Brazilian Institute of Statistics (Instituto Brasileiro de Geografia e Estatistica [IBGE], 2009), relative to 2006, private rural area corresponds to $33.6 \%$ of the land or 306661 ha. A more current analysis conducted by the State of Mato Grosso in association with local 
NGO Instituto Centro de Vida (ICV) and The Nature Conservancy (TNC) showed that while the area occupied by settlement lots correspond to $14 \%$ (127730 ha) of the municipal territory, other 236483 ha were found to be enrolled on the state's license system (MT et al., 2009), indicating that actually, at least 40\% (364213 ha) of the territory corresponds to private properties (Table 1).

\subsection{Data collection}

To contain deforestation in the Brazilian Amazon it is vital to primarily understand the roles and movements of the actors involved in the problem (Fearnside, 2008). In that sense, data for this study was gathered from March to June 2009, from interviews with landowners, and from the State's Environmental Secretary (SEMA-MT), the Municipal Environmental Secretary and State's Institute for Agriculture Defense (INDEA/MT). It clarified the municipality's deforestation drivers, colonization history, population dynamics, and rural practices.

For the purpose of this study, landowners have been classified as either ranchers or loggers. Ranchers have then been subdivided into small (property $<100 \mathrm{ha}$ in size, including settlement and private lots that usually are 50ha), and large (property $>100 \mathrm{ha}$ in size) landowners, while all loggers were classified as large landowners (property $>100$ ha in size).

"On the ground" deforestation rates, along with current rural activities, adopted production systems, history of occupation and perspectives for REDD implementation were obtained with a semi-structured interview conducted with a total of 61 landowners who based their activities on cattle ranching. They were visited on both private and settlement lots areas, interconnected and connected to downtown Cotriguaçu by badly conserved dirt roads. Time and transportation constrictions allowed for the conduction of interviews in 14 large properties, 20 small colonizer's lots and 27 settlement lots.

An official estimation of the total number of operating logging companies was not available, so all visibly working sawmills found on the roads surrounding Cotriguaçu were visited. From a total of six visited companies, four owners agreed to be interviewed, and were inquired on the timber extraction methods adopted by their companies, destination of extracted wood, location and size of used area, and legal problems related to timber extraction.

Relevant information that helped construct the scenario for further analysis were also obtained from open interviews with local forest engineers, the current Secretary of Agriculture of Cotriguaçu, members of the State Secretary of Environment (SEMA) and the Brazilian Institute for Environment and Natural Renewable Resources (IBAMA), and local academic scholars. Official deforestation rates for the municipality were obtained from INPE (Instituto Nacional de Pesquisas Espaciais).

\subsection{Cotriguaçu's scenario}

When the colonization process started in Cotriguaçu, in 1984, landowners were given incentives to clear all the legally convertible area ( $50 \%$ of the property by then), and were given a subsidy from the national government to plant mainly rice crops. This process took place in a period when the federal government feared foreign invasions in the Amazon and therefore, implemented several measures to incentivize its occupation and safeguard the national territory. In the case of Cotriguaçu, besides subsidizing the crops, the government also bought and stocked almost all the entire production, for there was not enough market to absorb it in the area and transportation costs were too high due to bad road conditions.

With the change in the federal government in 1990, these funds were cut. Surrounded only by dirt roads and without any industries to process the grains, colonizers had to find other income generating options that would not take too much investment and at the same time, be profitable enough to pay for the high transportation costs. Cattle ranching then became the activity that best suited the situation due to three main reasons, as explained by Romeiro et al. (2004): cattle transported itself to the market; beef brought lower risks of losing out on the investments because it was easily sold and prices didn't fluctuate as much as agricultural crops; and finally, if producers wanted to sell their land, a property with pasture would be worth much more than a forested one.

Nowadays, since the same infrastructural conditions are still found, cattle ranching has been adopted as the main income activity by most farmers that move to Cotriguaçu, including settlers, and together with a few but representative logging companies, constitute the base of a land use system very common in the region, where eventually all land is converted to pasture.

In this model, so common in the Amazon, clearing of the land first starts with hard wood extraction conducted by both loggers and cattle ranchers. The latter sells the extracted wood to loggers, and continues to clear the land through the practice of slash and burn to convert it to pasture. Loggers, in their turn, either sell their land, extremely degraded by the logging activity, in small lots to rural producers, or keep it and transform it into 
pasture, since most of them also practice cattle ranching as an alternative rural activity. In either case, the final land-use of areas previously occupied by primary forest in any case is always pasture for the cattle ranching activity (Ferreira et al., 2005; Kirby et al., 2006) (Fig. 2).

\subsection{Current drivers of deforestation in Cotriguaçu}

The northern region of Mato Grosso, where Cotriguaçu is located, belongs to the so called "Arc of Deforestation", an area where the agribusiness frontier is known to push deforestation forward into the Amazon. In Cotriguaçu, rural businesses were found to be centered on cattle ranching and timber extraction, which, together represent the basis of the local economy and hence the greatest threat to the local forest.

\subsubsection{Logging in Cotriguaçu}

Logging has been one of the main forms of land use in the Amazon, playing an important role in its economy but also in its destruction, either because a great portion of it is illegal (takes place inside protected areas or does not follow SFM practices), or because it usually doesn't take into account the limits of the natural resource's potential for renewal (Carvalho et al., 2009). Higuchi et al. (2009) show for example that from 1997 to 2003, $81 \%$ of all deforestation in the Amazon was illegal, and from the wood production of the 1996-97 year, only $25 \%$ came from authorized cutting, while $68 \%$ was from undefined origin. In Cotriguaçu, where importance of logging in the local economy has recently decreased but still plays an important role, a survey conducted by Finger (unpublished data) in 2004 showed that 12 out of the 15 active logging companies practiced illegal logging not only on their own properties (inside protected areas) but also in other areas like vacant land (terra devoluta). The mining aspect of logging activity in Cotriguaçu was also revealed on the same survey conducted by Finger, which showed that 53\% of the timber extracted in 2004 came from non-SFM areas.

When questioned about their practices in 2009 , loggers cautiously agreed to give some information about their properties. Two of the respondents gave estimations of $8 \%$ and $50 \%$ of deforestation rate inside their properties, while another one declared to have only degraded the entire area. The remaining respondent refused to give any information on the share of area conserved. Furthermore, three of the four interviewed subjects claimed to be currently conducting wood extraction only under SFM, but refused to give precise information on the number and size of their properties. The remaining respondent argued that, given the small scale of his business and the high level of bureaucracy met to obtain the license for logging activity, the adoption of SFM would not allow him to keep the business running.

According to a report obtained from SEMA-MT, until June of 2009, only three SFM projects had been approved in the Cotriguaçu area, from which only one belonged to one of the interviewed logger. This situation shows that the definite establishment of SFM on the entire property area under exploitation should be one of the main tools adopted by REDD in Brazil to slow down or even stop over-deforestation in the long run (Scholz and Schmidt, 2008).

\subsubsection{Cattle ranching in Cotriguaçu}

Since "Operation Curupira" - conducted in the state by the Federal Police, the Ministry for the Environment (MMA), Ibama and the Federal Prosecution Service (MPF) - unveiled cases of fraud and corruption in the licensing of forest activities in the year of 2005, many logging companies in the area have been closed down. This has caused logging activity to sharply decrease and the importance of cattle ranching in the local economy to grow.

Up to 2006, a total of 94310 ha of pasture had been established in previously forested areas distributed among 1574 agricultural establishments in Cotriguaçu, according to IBGE (2009). The number of rural properties with pasture showed a sharp increase especially in the year of 2005 (Fig. 3), when deforestation reached its highest rate in the area (Fig. 4) and one year before the largest increase in the herd was found (Fig. 5) (Secretaria de Estado de Planejamento e Coordenação Geral [SEPLAN], 2006; IBGE, 2009; INDEA, personal communication; Instituto Nacional de Pesquisas Espaciais, 2009).

The connections found among deforestation rates, pasture area and herd size in Cotriguaçu show that large increases in the cattle herd always follow an increase in deforestation rates, which are concurrent with the increase in the area covered by pasture. That happens because in the Amazon region, farmers adopt the extensive ranching method, where animals are left to feed without care in a pasture that usually hasn't received any preparation. The support capacity of pastures using this method is very low when compared to that of a more intensive practice. In our survey for example we found an average of $0.55 \mathrm{AU}$ (animal units)/ha, which is low even when compared to the average of other municipalities in the same region that practice extensive ranching 
(0.8AU/ha) (Anuário da Pecuária Brasileira, 2008), hence the need to clear extensive areas to accommodate the herd increase.

With the foreseen increase in global demands for food, if nothing is done to change this production system, deforestation rates can only be expected to increase in the future. To change that trend in a way that does not bring prejudice to farmers, the best alternative is to invest in the intensification of the production system. Previous studies conducted by EMBRAPA have shown that the adoption of simple and inexpensive techniques such as fertilization of the soil, improved herd management and sanitary control could increase the support capacity of the already established pasture in at least $50 \%$ of the cases (Cezar et al., 2005; Valle et al., 1998), but despite knowing that, none of the 61 interviewed landowners were currently adopting these practices because in the end, although the production is lower in the extensive method, cattle still grows and reproduces under extremely low maintenance costs, resulting in a compensating financial return. (Romeiro et al., 2004). This trade off is particularly positive for large ranchers, who also manage other businesses in town and do not depend on the ranching activity for their income. For small farmers, however, an improvement in the production, even though small, would be welcome. Nevertheless, interviewed small farmers complained that government financial schemes that could serve as incentives for the adoption of better ranching techniques have been particularly difficult to get, since the environmental legislation determines that only landowners who have received a license declaring that their property fits the rules established by the environmental legislation can qualify for financial support. Since most landowners in Cotriguaçu are illegal in that aspect, as explained in section 3, they haven't been able to invest much in their properties, and so the extensive cattle ranching method is kept.

Small farmers also obtain a small share of income from dairy activity, so the intensification of ranching activity could represent an improvement on the milk production and an increase in their income too. Yet, further infrastructural improvements would also have to be made, since farmers complained that because Cotriguaçu is only connected to other municipalities by dirt roads and served by only one nearby dairy industry with little infrastructure, they face many difficulties in selling their milk, and specially in storing the production until it can be collected. Energy lines still do not cover the entire municipality's area, and, although these are currently being installed, the process takes time, and many distant properties cannot have refrigerators to store the milk products. Farmers informed the truck collecting milk from the properties is unable to reach them regularly, skipping visits at least once a week due to bad road conditions, and without appropriate storage, the entire production is lost. The presence of only two slaughter houses in neighboring municipalities also makes transportation an issue, and directs investments and profits to other locations.

\section{Implications of direct payments to landowners}

With the possible implementation of REDD schemes in the Mato Grosso State being stimulated by the local government and NGOs such as ICV and TNC (MT, 2009; Micol et al., 2008), and even publicly announced by local politicians as witnessed during data collection in the locality, all interviewed rural producers declared to be expecting direct compensations from REDD in the near future. When inquired about their perception on REDD, the landowners' general idea was that the mechanism would allow them to at least maintain the same level of profit obtained from their current rural activities, except that no more labor input would be needed, and persecution from environmentalists would cease to exist. To smallholders, REDD grew even more in importance since it was also seen as an opportunity to improve livelihood. This positive perception however, was based on incomplete information, since a framework has not yet been established and there are no certainties about the compensation mechanisms to be adopted or the implications they might generate.

In that sense, the analysis of landowners' legal and economic situation in Cotriguaçu was an important tool that helped visualize what would be the implication of a "direct payment" scheme, the most widely disseminated proposal for benefits distribution in Brazil. If compensations are directly paid to landowners as it happens in other models of PES schemes, there is a great risk that thousands of smallholders will be excluded from the scheme and benefits will be concentrated in the hands of wealthy farmers. As described from now on, two main issues could be identified as drivers for this inequality, which were mainly determined by the presence of the LFR rule and the importance generally given to additionality on REDD schemes.

Opportunity costs estimated using a model designed by Nepstad et al. (2007) to inform REDD negotiations show that US $\$ 2,75 /$ ton of carbon ${ }^{-y}$ or US $\$ 390 / \mathrm{ha}^{-\mathrm{y}}$ would more than pay off the usual profit from cattle ranching in the Amazon (< US\$50,00/ha). This estimation would satisfy even wealthy large landowners interviewed in Cotriguaçu, who said would consider it fair to be paid from US $\$ 110 / \mathrm{ha}^{-\mathrm{y}}$ to US $\$ 200 / \mathrm{ha}^{-\mathrm{y}}$. Direct payments analyzed from a distant point of view would then look like a win-win solution, where an affordable amount is paid to landowners who are happy to receive compensation that is worth more than their opportunity costs. 
However, for this scheme to work, Brazilian authorities must first decide whether REDD in the country will follow the environmental legislation or establish its own terms. According to the current Brazilian Forest Code, rural property owners in the Legal Amazon area are only allowed to use up to $20 \%$ of their property land and leave the remaining $80 \%$ as LFR. Based on this rule, Börner and Wunder (2008) describe four levels or processes under which deforestation currently occurs in the Brazilian Amazon, three being illegal ${ }^{1}$ and only one sanctioned by law, where landowners clear up to the $20 \%$ of their land area that are legally degradable. When questioned about the shares of conserved and used land on their properties, most landholders on our survey declared to have used more than the $20 \%$ legally allowed, with smallholders showing smaller extensions of conserved forest $(41.9 \%)$ than large landholders (68.1\%). Notably, while private owners in general have deforested about $50 \%$ of their properties, as it was determined by the Forest Code at the time the colonization process started in the area, settlers have on average used even larger extensions of land (29.9\%). This suggests that if it becomes a requirement to abide by this rule and payments are set to be only relative to the $20 \%$ legally degradable area in private properties, not only most landowners in Cotriguaçu will not qualify for direct compensations, but the poorest will be the ones with least chances of receiving direct compensation (Table 2). In that sense, although demanding responsibility from landholders for their illegal acts is rightful, it must be noticed that the LFR rule is particularly difficult to be followed by small property owners, who would hardly be able to obtain the necessary income from less than $20 \%$ of their property area under the current production model adopted.

A recent amendment proposal to the Forest Code in Brazil suggests the share of LFR to be reduced to $50 \%$ of the property area. This change would generate many consequences that are out of this study's scope, but to REDD, this could represent a broader inclusion of smallholders in some regions. In order to include small producers, REDD could also be established under its own regulations, which could ignore the requirement of the LFR and pay for avoided deforestation relative to the entire property area. This last idea has been presented by some authors, who see the situation as a trade off, or the price to be paid for forest conservation (Nepstad et al., 2007; Börner \& Wunder, 2008), but if the legislation is either changed or ignored, the accumulated deforestation rate found in Cotriguaçu suggests that still only large landowners would qualify for direct compensation, while the majority of smallholders would still end up with little or absent "environmental surplus" to be compensated for (Table 2). Ignoring the LFR could also generate a perverse incentive for further exploration of LFR areas, representing a risk that perhaps is much too great to be accepted.

Another solution for the LFR issue, presented by Nepstad et al. (2007), is that payments be relative only to areas bought before the establishment of a REDD program. In that case, the risk of perverse incentive would be lowered, but it would still exist as this act risks sending the message that can be bent to one's favor in Brazil, which is precisely the mindframe that needs to be changed to protect the forest.

The second issue that might lead to unequal distribution of benefits is the importance of additionality to REDD schemes. In essence, REDD's main goal is to lower the stock of carbon in the atmosphere. In that sense, areas that can guarantee higher reductions in emission in addition to what would happen in the absence of the scheme (Angelsen, 2009), or in other words, offer more additionality, are likely to attract the largest bulk of investments.

If this condition holds, it is most likely that compensation will be directed to large landholders, who own the majority of the private area in Cotriguaçu and also present the largest shares of remaining forest cover. Furthermore, if additionality is put at the forefront, the increase in opportunity costs generated by global demands for food will only increase interests in protecting areas under severe risk of deforestation. The little forested area still left untouched in small properties of Cotriguaçu (Table 2) would therefore be hardly targeted over the extent conserved areas in large properties belonging to wealthy owners, who also have more access to external markets. Besides smallholders, protected areas such as the Escondido Indigenous Territory and Juruena National Park in Cotriguaçu are in very isolated areas and have shown very low deforestation rates of $0.02 \%$ and $0.08 \%$ respectively, offering little additionality and probably attracting little interest from REDD funders.

Overall, when analyzed carefully, the situation shows that direct payments and the focus on additionality together would dramatically reduce the scope for REDD in Cotriguaçu and, instead of improving livelihood of local and indigenous communities, it would accumulate benefits on the hands of wealthy land owners.

\section{Conclusion and recommendation for future studies}

REDD has been pointed by some as possibly the last chance the world might have to avoid drastic changes to the global climate with a significant reduction on carbon emissions that would also represent the protection of most of the remaining forest cover in the world. Efforts in that area, although driven by the need to find solutions for environmental problems, also attempt to include social aspects, since human beings are a part of natural 
ecosystems and as such, will deeply influence the outcomes of any proposed solution. In that sense, two main criteria for REDD are that its actions towards emission reductions bring at the same time equitable, transparent and fair distribution of benefits, and that it should involve not only landowners but also local and indigenous communities (Angelsen \& Wertz-Kanounninkoff, 2008).

Rules under which the REDD mechanism will be established to achieve those goals in each country must be decided by national authorities, and in the case of Brazil, this study has shown that further attention must be given to the implications that might come from the currently proposed compensation scheme of direct payments to landowners. The analysis of local data collected in the Cotriguaçu municipality suggest that if additionality is put at the forefront of a direct payment scheme, the bulk of compensations from REDD will be directed to large landowners. Furthermore, if the national environmental legislation is also followed, thousands of smallholders will not even qualify for those compensations.

The situation found in Cotriguaçu shows that, if the REDD mechanism in Brazil is to be fair and act on cultural drivers that, in the end, are the ones which have caused the current rate of deforestation in the Amazon, REDD must be set by strict rules that should be followed nationwide. In that sense, the adoption of a national approach would not only guarantee that the same rules are applicable to all, but that also benefits be equally distributed to all actors. If emission reductions are accounted and credited for the whole country, a central organ can further distribute compensation among those who have joined the scheme in a fair way.

The compensation that will be paid to landholders, although needed as a way to incentivize obedience to the rules which clearly have not been followed in Brazil, should not only be relative to the amount of avoided deforestation, which would exclude most smallholders, but also to the efforts shown by those who have little or unattractive forested area to offer (additionality wise), so that fairness is achieved.

Alternative compensation schemes are clearly needed, and the authors suggest that further studies should consider the implementation of schemes where the focus will no longer be on direct payments, but probably on the creation of funds that separate the benefits according to the different kinds of expected expenditures, so that all actors involved in the scheme can have their share of compensation guaranteed. In the first approach, these funds could be targeted to governmental expenses, rewards for indigenous and local communities' good stewardship, to the recovery of environmental deficits, e.g. the area inside LFRs that has been degraded, and to actions that will allow the adoption of more sustainable rural practices instead of the exploitation style currently adopted in the Amazon, which in the case of Cotriguaçu can mean shifting towards more intensive land use through building of better roads, wider coverage of energy lines and other elements of infrastructure. To do so, further studies could more deeply investigate the actions according to each area and the shares that could be directed to each group.

In summary, investments on territorial organization, improved regulation, more rigid law enforcement, and education to change the way people relate to the land and the rules set to protect it, must be seen as the base for the establishment of a compensation scheme that should focus on the adoption of sustainable rural practices. Investments in these fields represent an investment in the forest itself, which is a fair, effective and efficient way to apply REDD funds.

\section{Acknowledgements}

We would like to thank Janaina Rocha and Robson Disarz for ideas and support on the elaboration of figures, and Pedro Simões for field work assistance. Field work could only be conducted due to the full support of Cotriguaçu's Secretary of Agriculture's staff. We are also very thankful to the Ministry of Education, Culture, Sports, Science and Technology of Japan (MEXT) for providing a scholarship to C.S., and the International Tropical Timber Organization (ITTO) for providing fellowship support to C.S.

\section{References}

Alvarado, L.X.R., \& Wertz-Kanounnikoff, S. (2008). Why are we seeing "REDD”? An analysis of the international debate on reducing emissions from deforestation and degradation in developing countries Analyses 01, Paris: Institut du développement durable et des relations internationales (IDDRI).

Angelsen, A. (2009). Glossary. In A. Angelsen, M. Brockhaus, M. Kanninen, E. Sills, W.D. Sunderlin, \& S. Wertz-Kanounnikoff (Eds.), Realising REDD+: National strategy and policy options. Bogor Barat: Center for International Forestry Research, pp. 309-319.

Angelsen, A., \& Wertz-Kanounnikoff, S. (2008). What are the key design issues for REDD and the criteria for assessing options? In Angelsen, A. (Ed.), Moving ahead with REDD: issues, options and implications. Bogor Barat: Center for International Forestry Research, pp. 11-21. 
Angelsen, A., Streck, C., Peskett, L., Brown, J., \& Luttrell, C. (2008). What is the right scale for REDD? In Angelsen, A. (Ed.), Moving ahead with REDD: issues, options and implications. Bogor Barat: Center for International Forestry Research, pp. 31-40.

Anuário da Pecuária Brasileira. (2008). São Paulo, SP: Agra FNP.

Börner, J., \& Wunder, S. (2008). Paying for avoided deforestation in the Brazilian Amazon: from cost assessment to scheme design. International Forestry Review, 10, 496-511.

Börner, J., Wunder, S., Wertz-Kanounnikoff, S., Tito, M.R., Pereira, L., \& Nascimento, N. (2010). Direct conservation payments in the Brazilian Amazon: scope and implications. Ecological Economics, 69, 1272-1282.

Carvalho, J.O.P., Silva, J.N.M., Pokorny, B., Sabogal, C., \& Zweede, J. (2009). Systems for SFM. Tropical Forest Update, 18, 9-11.

Cezar, I.M., Queiroz, H.P., Thiago, L.R.L.S., Cassales, F.L.G., \& Costa, F.P. (2005). Sistemas de produção de gado de corte no Brasil: uma descrição com ênfase no regime alimentar e no abate (1st. ed.). Campo Grande: Embrapa Gado de Corte.

Costa, P.M., Stuart, M., Pinar, M., \& Phillips, G. (2000). Elements of a certification system for forestry-based carbon offset projects. Mitigation and adaptation strategies for global change, 5, 39-50.

Fearnside, P.M. (2005). Desmatamento na Amazônia brasileira: historia, indices e consequencias. Megadiversidade, 1, 113-123.

Fearnside, P.M. (2008). The roles and movements of actors in the deforestation of Brazilian Amazônia. Ecology and Society, 13(1): 23. Retrieved July 10, 2010, from http://ecologyandsociety.org/vol13/iss1/art23/

Ferraz, S.F.B., Vettorazzi, C.A., Theobald, D.M., \& Ballester, M.V.R. (2005). Landscape dynamics of Amazonian deforestation between 1984 and 2002 in central Rondonia, Brazil: assessment and future scenarios. Forest Ecology and Management, 204, 67-83.

Ferreira, L.V., Venticique, E., \& Almeida, S. (2005). O desmatamento na Amazônia e a importância das áreas protegidas. Estudos Avançados, 19, 157-166.

Higuchi, N., Pereira, H.S., Santos, J., Lima, A.J.N., Higuchi, F.G., Higuchi, M.I.G., \& Ayres, I.G.S.S. (2009). Governos locais amazônicos e as questões climáticas globais (1st ed.). Manaus: INPA.

Instituto Brasileiro de Geografia e Estatistica. (2009). Censo Agropecuario. Rio de Janeiro, RJ: IBGE. Retrieved from http://www.ibge.gov.br/home/estatistica/economia/agropecuaria/censoagro/default.shtm

Instituto Nacional de Pesquisas Espaciais. (2009). Estimativas Annuais de Desmatamento. Projeto Prodes. Retrieved from http://www.obt.inpe.br/prodes/index.html

Intergovernmental Panel for Climate Change. (2007). Contribution of Working Group III. In Metz, B., Davidson, O.R., Bosch P.R., Dave, R., \& Meyer, L.A. (Eds.), Fourth Assessment Report of the Intergovernmental Panel on Climate Change. UK: Cambridge University Press. Retrieved May 15, 2008, from http://www.ipcc.ch/ipccreports/ar4-wg3.htm

Kirby, K.R., Laurance, W.F., Albernaz, A.K., Schroth, G., Fearnside, P.M., Bergen, S., Venticinque, E.M., \& da Costa, C. (2006). The future of deforestation in the Brazilian Amazon. Futures, 38, 432-453.

Malhi, Y., Roberts, J.T., Betts, R.A., Killeen, T.J., Li, W., \& Nobre, C.A. (2008). Climate change, deforestation and the fate of the Amazon. Science, 319, 169-172.

Mato Grosso State Government (MT), Instituto Centro de Vida, \& The Nature Conservancy (2009). Northwest Mato Grosso REDD pilot project outline. Retrieved from: http://www.icv.org.br/w/library/1148866054nwmt_reddpilot_dec09.pdf .

Micol, L., Andrade, J., \& Börner, J. (2008). Redução das Emissões do Desmatamento e da Degradação Florestal (REDD): potencial de aplicação em Mato Grosso. Cuiabá, MT: Instituto Centro de Vida.

Nabuurs, G.J., Masera, O., Andrasko, K., Benitez-Ponce, P., Boer, R., Dutschke, M., Elsiddig, E., Ford-Robertson, J., Frumhoff, P., Karjalainen, T., Krankina, O., Kurz, W.A., Matsumoto, M., Oyhantcabal, W., Ravindranath, N.H., Sanz Sanchez, M.J., \& Zhang, X. (2007). Forestry. In Metz, B., Davidson, O.R., Bosch P.R., Dave, R., \& Meyer, L.A. (Eds.), Climate Change 2007: Mitigation. Contribution of Working Group III to the Fourth Assessment Report of the Intergovernmental Panel on Climate Change. Cambridge, UK and New York, NY, USA: Cambridge University Press. 
Nepstad, D.C., Stickler, C.M., \& Almeida, O.R. (2006). Globalization of the Amazon soy and beef industries: opportunities for conservation. Conservation Biology, 20, 1595-1603.

Nepstad, D., Soares-Filho, B., Merry, F., Moutinho, P., Rodriques, H.O., Bowman, M., Schwartzman, S., Almeida, O., \& Rivero, S. (2007). The costs and benefits of reducing carbon emissions from deforestation and forest degradation in the Brazilian Amazon. A Report for the United Nations Framework Convention on Climate Change (UNFCCC) Conference of the Parties (COP), Thirteenth Session. Falmouth, MA: Woods Hole Research Center.

Nepstad, D.C., Stickler, C.M., Soares-Filho, B., \& Merry, F. (2008). Interactions among Amazon land use, forests and climate: prospects for a near-term forest tipping point. Phil. Trans. R. Soc. B., 363, 1737-1746.

Ramankutty, N., Gibbs, H.K., Achard, F., Defriess, R., Foley, J.A., \& Houghton, R.A. (2007). Challenges to estimating carbon emissions from tropical deforestation. Global change biology, 13, 51-66.

Romeiro, A.R., Mangabeira, J.A.C., \& Valladares, G.S. (2004). Biodiversidade, reflorestamento e agropecuária no Brasil/ Biodiversity, reforestation and agriculture in Brasil. Florestar Estatistico, 16, 15-22.

Scholz, I., \& Schmidt, L. (2008). REDD: opportunities for SFM. In Holopainen, J., \& Desighn, M. (Eds.), Financing Sustainable Forest Management. Wageningen: Tropenbos International, pp. 141-145.

Secretaria de Estado de Planejamento e Coordenação Geral. (2006). Anuário Estatístico de Mato Grosso (vol. 28). Cuiabá, MT: Governo do Estado de Mato Grosso Secretaria de Estado de Planejamento e Coordenação Geral Cuiabá. Retrieved from http://www.anuario.seplan.mt.gov.br/2007/

Trancoso R., Schietti, J., \& Filho, A.C. (2007). Padrões de desflorestamento na Amazônia legal: diferenças espaciais e temporais das mudanças na cobertura da terra. Annals of the XIII Simpósio Brasileiro de Sensoriamento Remoto, Florianópolis, Brazil: INPE, 3187-3194.

Valle, E.R., Andreotti, R., \& Thiago, L.R.L.S. (1998). Estratégias para aumento da eficiência reprodutiva e produtiva em bovinos de corte. (1st ed.). Campo Grande: EMBRAPA-CNPGC (Chapter 12).

Walker, R., \& Moran, E. (2000). Deforestation and cattle ranching in the Brazilian Amazon: external capital and household processes. World Development, 28, 683-699.

\section{Notes}

Note 1. The three levels of illegal deforestation happen when: (i) landowners make illegal use of land inside their Legal Forest Reserve (LFR) generating what is called "environmental deficit"; (ii) land grabbers and/or squatters invade vacant or weakly enforced state land (terra devoluta) and clear it in the hope of establishing land tenure over time, and (iii) land is invaded in protected areas like national parks, indigenous land, etc.

Table 1. Land distribution in Cotriguaçu, Mato Grosso, according to IBGE (2009) and MT et al. (2009)

\begin{tabular}{lcccc}
\hline \multirow{2}{*}{ Land category } & \multicolumn{2}{c}{ IBGE } & \multicolumn{2}{c}{ Mato Grosso } \\
\cline { 2 - 5 } & ha & $\%$ & ha & $\%$ \\
\hline Private area & 306661 & 33.6 & $364213<$ & $40<$ \\
$\quad$ Private lots & - & - & $236483<$ & $26<$ \\
$\quad$ Settlement lots & - & - & $127730<$ & 14 \\
Indigenous territory & 168938 & 18.5 & 164224 & 18 \\
Conservation units & 134116 & 14.7 & 134116 & 14.7 \\
Undesignated land & 302642 & 33.2 & 249805 & 27.3 \\
\hline Total & 912358 & 100 & 912358 & 100 \\
\hline
\end{tabular}


Table 2. Average area (ha) by household and by land-use category in Cotriguaçu, Mato Grosso

\begin{tabular}{cccccccccc}
\hline $\begin{array}{c}\text { Household } \\
\text { category }\end{array}$ & $\mathrm{N}$ & \multicolumn{2}{c}{ Forest } & \multicolumn{2}{c}{ Pasture } & \multicolumn{2}{c}{ Others } & \multicolumn{2}{c}{ Total } \\
\hline & & ha & $\%$ & ha & $\%$ & ha & $\%$ & ha & $\%$ \\
\hline Small & 47 & 1160 & 41.9 & 1459 & 52.7 & 149 & 5.4 & 2768 & 100 \\
$\quad$ private & 21 & 858 & 48.7 & 843 & 47.9 & 60 & 3.4 & 1761 & 100 \\
settlers & 26 & 302 & 29.9 & 616 & 61.2 & 89 & 8.9 & 1007 & 100 \\
Large - private & 14 & 18047 & 68.1 & 7121 & 26.9 & 1332 & 5 & 26500 & 100 \\
\hline
\end{tabular}

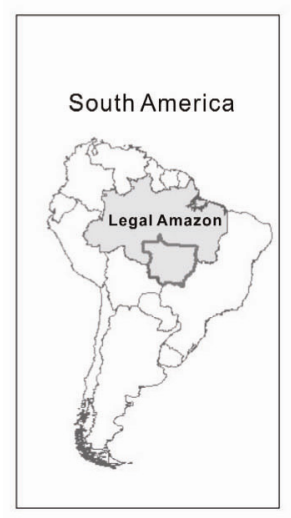

Legend. Cotriguaçu

Municipalities

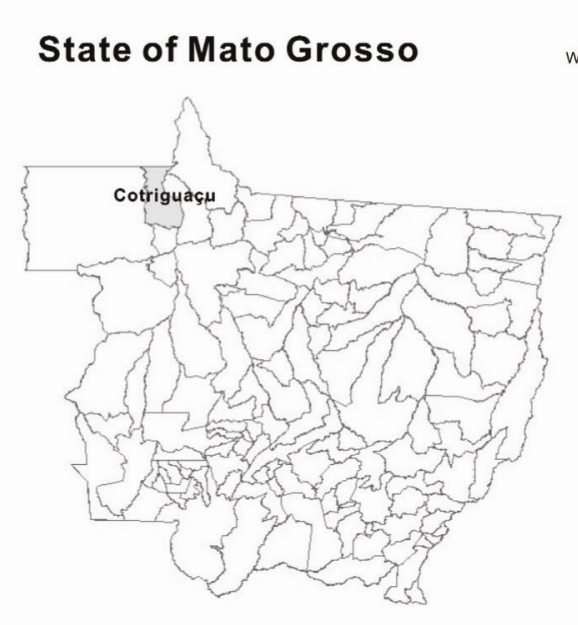

$\frac{T^{2}}{n}$

Scale: \begin{tabular}{lllll}
\hline & 125 & 250 & 500
\end{tabular}

Figure 1. Location of the Cotriguaçu municipality in the Legal Amazon area and in the State of Mato Grosso, Brazil

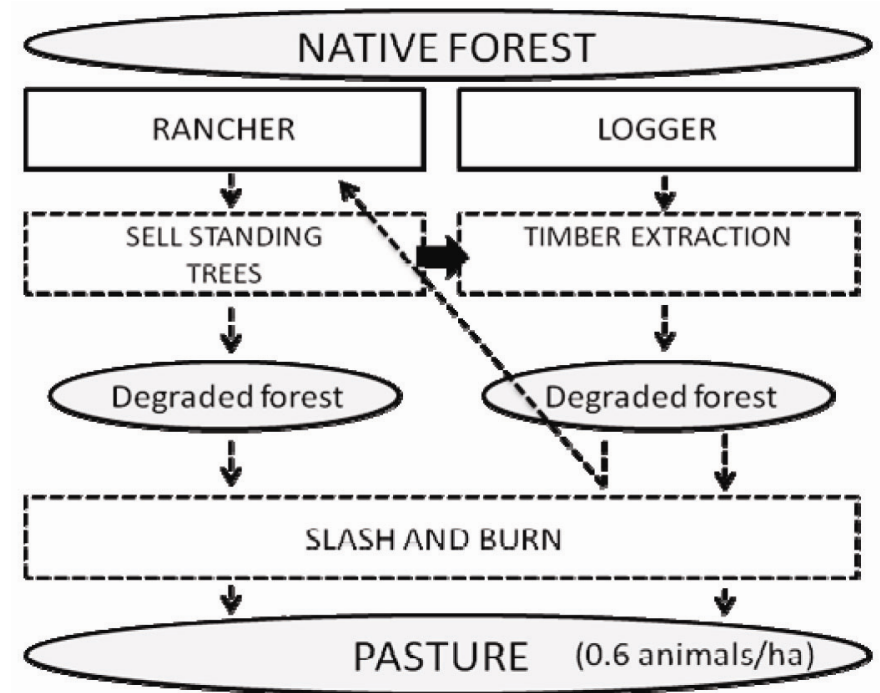

Figure 2. Land-use system in Cotriguaçu, Mato Grosso, Brazil 


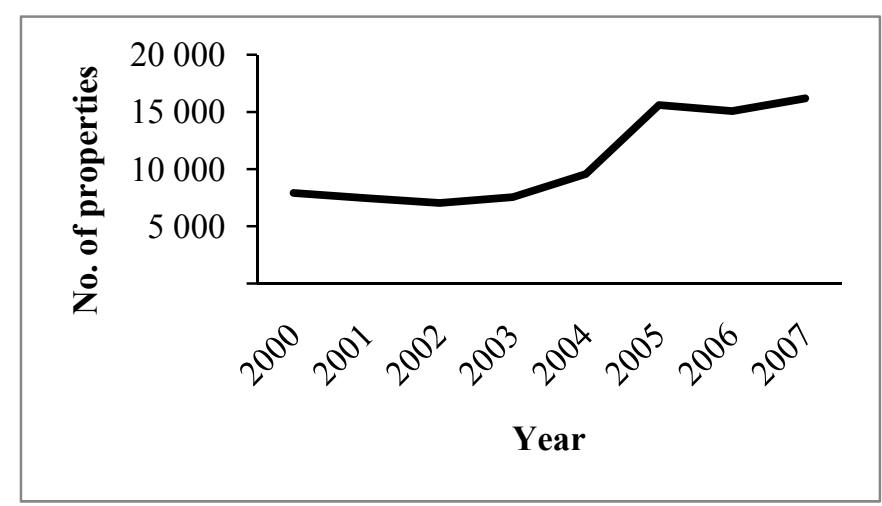

Figure 3. Number of rural properties with pasture in Cotriguaçu-MT (IBGE 2009)

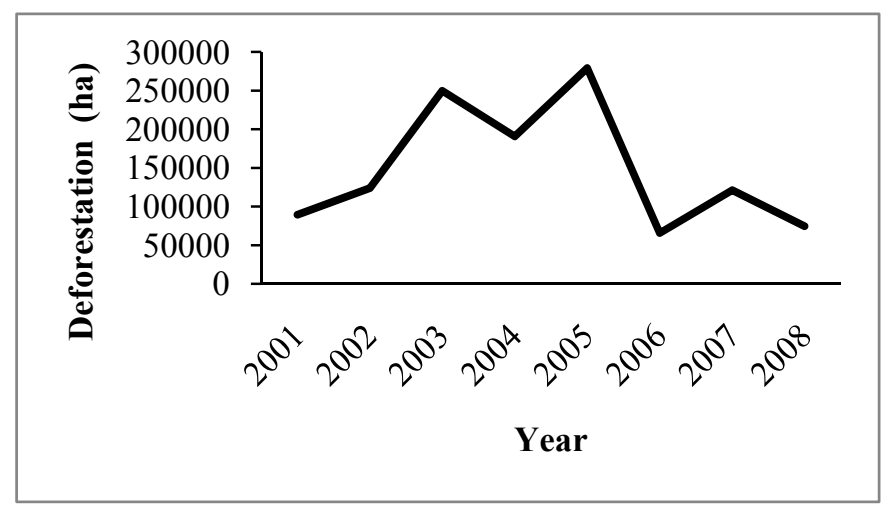

Figure 4. Deforestation rates in Cotriguaçu-MT (INPE 2009)

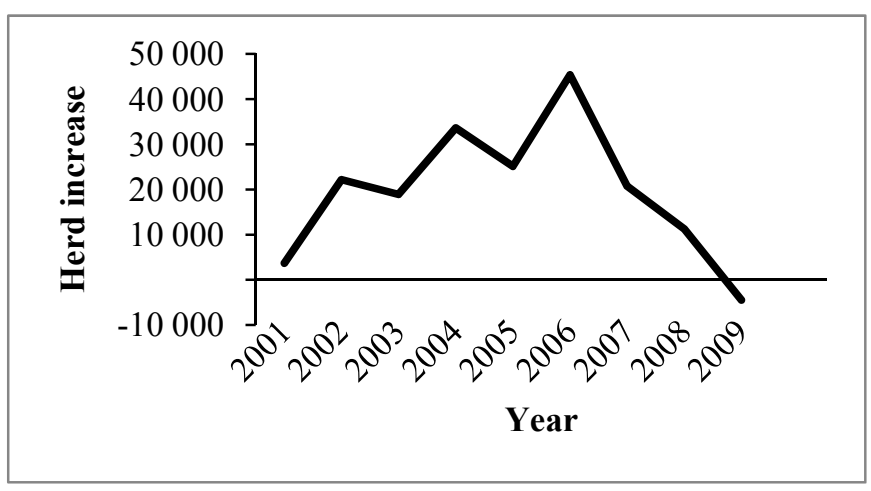

Figure 5. Evolution of cattle herd in Cotriguaçu-MT. *Data from 1999-2006 were obtained from SEPLAN. Data from 2007-2009 were obtained from Indea-MT 